\title{
Financial Performance of the SMEs Sector in Kosovo: An Empirical Analysis Using the DuPont Model
}

\author{
Halit Shabani, Fisnik Morina*, Agonis Berisha \\ Faculty of Business, University 'Haxhi Zeka', Peja 30000, Republic of Kosovo
}

Corresponding Author Email: fisnik.morina@unhz.eu

https://doi.org/10.18280/ijsdp.160503

Received: 23 April 2021

Accepted: 29 July 2021

\section{Keywords:}

SMEs, DuPont model, return on equity, utilisation of assets, multiplier of capital, profit margin, JEL Classification: D82, G11, G210, G21, F21, M21

\begin{abstract}
The aim of the study is to illustrate the advantages of the DuPont model, namely the division of complex indicators into the factors of which they are composed. This allows us to determine the main causes and the relationship of changes in the complex performance indicators of small and medium enterprises operating in Kosovo. This research takes 40 small and medium-sized enterprises operating in Kosovo during the period 2016-2018 and uses the DuPont model of financial analysis based on capital analysis of the return model to analyse and measure their financial performance. This research will be realised with the statistical software SPSS, using ROE (return on equity) as the dependent variable and AU (Assets utilisation), EM (equity multiplier) and PM (profit margin) as the independent variables. The fact that companies around the world operate across volatile markets as well as with extremely fierce competition adds to the need for constant monitoring of the financial condition of the enterprise itself as well as its competitors. For various reasons, the state and other actors in the market also need knowledge about this issue. This research is a summary of information from multiple sources in order to provide a description of the reality faced by enterprises when compiling financial reports. By reading this paper, the reader will be able to expand their knowledge about the process of compiling and reporting financial results.
\end{abstract}

\section{INTRODUCTION}

This study is an attempt to provide information obtained from various sources in order to compile a compact set of materials that will serve as a guide for each individual who aims to gain knowledge of how to evaluate the success of enterprises through financial statements.

Financial analysis, as an assessment and determinant analysis of the financial situation of a company, is one of the most important and meaningful analyses that can be done for a company. The methods and models used by this analysis highlight the financial health of a firm. First, a review of the literature on the Du Pont model and the benefit of small and medium-sized enterprises (SMEs) will be presented, explaining and analyzing the key concepts of financial analysis. Second, a comparative analysis of the financial markets of the SMEs selected for this study will be presented based on the indicators of the Du Pont Model. Third, empirical data and study findings will be analysed and hypotheses will be tested. At the end of the research, the conclusions, recommendations and literature used will be presented.

The DuPont model is a modified factor analysis that allows the determination of which factors cause the difference between the loss and profit of SMEs based on the return on equity (ROE) indicator and other elements that characterise other factors in the financial activity of SMEs. Simply put, the factors influencing ROE are broken down to determine which factors have a greater or lesser impact on return on equity. Meeting these needs through the correct use of resources will make some companies more successful than other companies, either in the real value they give to the company or in the value they have in the stock market rankings of the world [1-3]. According to Liberto [4], small and medium-sized enterprises are businesses that hold income and assets or employ a number of people below a certain threshold. Each country has its own definition of what constitutes an SME. Some size criteria must be met and the industry in which the company operates is also occasionally considered. According to Aliriani [5], economists have different views on the current contributions of SMEs to an economy. Some argue that the SME sector is an essential part of any economy because it in general plays an important role in innovation, job creation and economic growth. Others argue, however, that large enterprises are more effective in producing the desired levels of economic growth and development.

According to Carlson [6], the Dupont model is a valuable tool for business owners or investors to use to analyse their return on investment (ROI) or return on assets (ROA). The extended DuPont model also allows the analysis of return on equity. There are many financial reports that a business owner can use to analyse the possible financial situation scenarios of companies. Using the DuPont model allows the business owner to identify the firm's profitability and analyse which firm activities are most profitable. According to Demmer [7], a DuPont analysis is a preferred method for estimating a firm's market value, thereby showing a company's leverage to improve future profitability through more efficient utilisation of its assets. According to Collier [8], since ROA also affects profitability and efficiency, a firm's operational decisions regarding planning and control will focus on increasing ROA; 
however, the first modification of the DuPont model shifted the focus from ROA to ROE and included debt or 'leverage' as a third area. This modification made the DuPont model a powerful tool for strategic decision-making within an organisation to increase ROE. According to Almazari [9], there are many different models of financial analysis for any business in the private sector which describe how well the business operates. Among these various methods, the DuPont model, created in the early $1900 \mathrm{~s}$, is still a valid model to be used for profitability assessment. Many authors have not yet applied this model in their research at the level of risk, but if we as researchers have the necessary knowledge and are specialised in the field of risk management, then this model can be very valuable. The DuPont model was applied by F. Donaldson Brown, who through this method solved many of the financial problems of General Motors, and it has since been considered an important model for financial analysis. However, this model has not been used in the safety community for risk prioritisation or impact analysis.

According to Rogova [10], DuPont analysis effectively revealed the efficiency factors which, in turn, influenced the investment attraction for Russian oil extraction companies. It was also found that the possibility of splitting ROE into different profit ratios created a strong advantage in that ROE shows profitability and efficiency from the shareholders point of view. According to Brigham [11], the modified DuPont model was a powerful tool to illustrate the relationship between a company's income statement and its balance sheet and to develop direct strategies to improve the firm's return on equity.

The aim of the study is to illustrate the advantages of the DuPont model, namely the division of complex indicators into the factors of which they are composed. This allows us to determine the root causes and relationship of changes in complex SME performance indicators. With the help of the factor analysis scheme of key indicators, it is possible to clearly define the impact of primary factors on the formation of complex indicators, to give their comparative characteristics and to determine the reasons for their change. The challenges of securing capital encourage these companies to strive to perform as well as possible and to have financial reports that are as convincing as possible in order to attract investors; herein lies the importance of knowing financial analysis. This study will have scientific significance, as small and medium-sized enterprises have greater participation in Kosovo's market and in the economic development of Kosovo. Through this research, we can measure the profitability of the rate of return on equity of SMEs. This study will first provide an analysis of the financial statements or reports of SMEs in Kosovo. Second, the paper will provide accurate analysis regarding the situation and framework of financial statements of SMEs in the Kosovo market. Thus, the framework of instruments for the analysis of financial statements is important in terms of the elements related to the structures of enterprises which are related to the financial position of SMEs.

The structure of this scientific paper is divided into 5 sections. The first section presents the literature review based on studies by various authors who have analyzed the performance of different sectors of the economy through the DuPont Model. In the second section is elaborated the sector of SMEs in Kosovo, performance, role and sectoral structure, while in the third section is presented a comparative analysis through linear trends which include the main variables of this study. The fourth section presents the description of the scientific research methodology, while the fifth section presents the econometric results and empirical findings of this study. At the end are presented the conclusion and recommendations derived from this study.

\section{LITERATURE REVIEW}

For every business in the private and public sector, there are many models that can be used to describe how well the business is functioning. Among these, the DuPont model, created in the early $1900 \mathrm{~s}$, is still a valuable model to use for profitability assessment, but it is obviously not used in the safety community for risk prioritisation or impact analysis. In the studies of different authors, the advantages and disadvantages of the DuPont model for analyzing the financial performance of different companies have been studied. Therefore, the views of the authors regarding the DuPont model are divided into two categories, the authors who have presented the advantages of the DuPont model in analyzing the financial performance of companies and the authors who have presented in their studies the disadvantages of this model. The DuPont model starts with the standard equation for ROA and divides it into two component ratios, one that focuses on the income statement and one that relates to balance sheet revenue [12]. This model has been modified twice since its initial development in 1918 by author F. Donaldson Brown, an engineer who used it to better understand the flow of a company's finances and which managed to recognise a mathematical relationship between return and return on equity (ROE) that is determined by return on assets (ROA) [13].

DuPont analysis has many advantages and is thus widely used, but it also has some limitations. From a performance appraisal point of view, DuPont analysis can only show financial information and cannot reflect the strength of the enterprise. DuPont analysis mainly focuses on short-term financial results and ignores long-term value creation. Furthermore, financial indicators reflect the operating performance of the enterprise in the past, measuring measure the ability of industrial enterprises to meet the requirements of the time [14]. But in the current information age, customers, suppliers, employees and technology innovators increasingly influence enterprise operating performance, and DuPont analysis is powerless in these respects. Moreover, DuPont analysis cannot solve the problem of the valuation of intangible assets which is very important to increase the competitiveness of enterprises in the long run. Despite all these obstacles, DuPont analytics are still the most commonly used tactics in companies around the world. The main reason is that enterprises nowadays combine the classic theories of DuPont analysis with the modern goal of financial management. Enterprises design a new DuPont analysis method based on the combination of the goal of maximising enterprise value and the goal of maximising stakeholder interest. In this way, stakeholders not only include the shareholders of an enterprise but also consist of creditors, business operators, customers, suppliers, employees and government. All these factors are essential for the financial management of enterprises. Damage to the interest of each stakeholder of the enterprise is not conducive to the sustainable development of the company nor is it conducive to achieving the maximum value of the enterprise. In other words, the ultimate goal of the new DuPont analysis is within the framework of law and morality, under the premise of 
harmonious development, effectively balances the interest of the parties of the companies and realises the maximisation of the value of the enterprise.

The DuPont analysis formula is more comprehensive than the simple return on equity formula because it provides insights into the individual performance indicators that drive a company's ROE. While the simple ROE formula tells you what a company's ROE ratio is, the DuPont analysis formula tells you how much impact each individual component has on the company's ROE ratio. This makes it possible for financial decision makers to identify company strengths and areas of opportunity and decide where to make adjustments to increase business ROE. Investors can also use the DuPont model to help them make more informed investment decisions based on a detailed comparison of strengths and opportunity areas from ROE reports of similar companies [15]. According to Buyukarikan, financial statements can be used as a tool to measure the financial status and performance of the business and make the right decisions about the business. In this sense, DuPont is a useful and simple tool to the measure financial performance of businesses [16]. According to Levent et al, capital gain analysis can also be performed in the DuPont financial analysis system based on the relationship between rates. When performing the equity return analysis, three variables are used, namely, net profit margin (net profit / net sales), asset turnover rate (net sales / total assets) and capital multiplier (total assets / total of equity); net sales and total assets are simplified to equity. Profit ratio is also achieved (net profit / total capital) [17]. According to Turner, et al, the DuPont description is sometimes referred to as the DuPont model or DuPont equation. The analysis was originally created by the DuPont Corporation as an accounting identity that divides capital holder returns into three components [18].

According to Karadeniz et al., as a measure of business performance, return on wealth and return on capital reveal information about the financial performance of businesses. In this context, DuPont analysis is important in terms of discovering the profitability of enterprises, determining the factors that affect profitability and identifying shortcomings [19]. According to Botika, ROE is the most important part of DuPont analysis. Many professional books highlight the DuPont method for financial report analysis. The use of DuPont analysis supports a company in dividing profits from investment capital measures, such as ROA, into two components: net profit and total asset turnover [20]. According to Risal, DuPont analysis is considered as one of the most important tools for financial analysis. Most multinational and large companies typically use DuPont analytics to analyse the performance of their businesses [21]. According to Kim, DuPont analysis calculates variables from the income statement and balance sheet to determine a firm's return on equity (ROE) and return on investment (ROI). DuPont analysis is based on return on equity analysis (ROE) and return on investment (ROI). Return on equity distributes performance across three components: net profit margin, total asset turnover and capital multiplier [22]. According to Oriskóová and Pakšiová, DuPont analysis links the balance sheet to the profit or loss statement and allows the identification of the strongest and weakest aspects of financial performance. For example, a high positive ROE may seem excellent. However, it does not exclude the possibility that the company has large losses and that its loss and capital are negative, but it instead reflects a very positive ROE due to mathematical rules in which two negative values are eliminated [23].

Return on equity or ROE is a profitability ratio that measures a firm's ability to generate profits from its shareholders' investments in the company. In other words, the return on equity ratio shows how much profit each euro of ordinary shareholder capital generates. ROE is also indicative of how effective management is in using equity financing to finance operations and grow the company [24]. DuPont analysis has resulted in the use of the detailed description of $\mathrm{ROE}$ as one of the performance indicators of the company's profitability. ROE is a report that shows the company's ability to generate returns for its shareholders. It is considered important to conduct this analysis periodically, especially to identify strengths and weaknesses in financial management in order to establish the appropriate strategy to respond [25]. Below is the ROE equation:

\section{$R O E=$ Net Income / Share Capital}

Return on equity (ROE) is an indicator of financial performance calculated by dividing net income by shareholders' equity. Given the fact that the shareholders' equity is equal to a company's assets minus its debt, ROE is considered the return on net assets. ROE also provides a simple metric for estimating return on investment. By comparing the ROE of a company with the industry average, something can be said about the competitive advantage of the company. ROE can also provide an overview of how company management is using equity financing to grow the business. Capital multiplier - Investors who are more accustomed to traditional debt ratios can confuse the ratio with the DuPont Equity Amount. The equity multiplier compares equity with total assets, not just total debt. The division of the company's total assets into equity results in the equity multiplier. For example, a company with assets of 150 million euros and capital of 50 million euros has a capital multiplier of 3.0 (150 million / 50 million). Companies that are more creditworthy have higher equity multipliers. A larger multiplier corresponds to a larger ROE number. However, a company that is already relatively profitable from disbursement may not be well advised to increase its debt burden, or it may take on debt and go bankrupt [26]. The net profit margin is equal to how much revenue or net profit is generated as a percentage of revenue. It is the ratio of net profit to revenue for a company or business segment and is usually expressed as a percentage but can also be represented in decimal form. The net profit margin illustrates how much of every euro of revenue collected by a company translates into profit. Net profit margin is one of the most important indicators of a company's financial health. By tracking increases and decreases in its net profit margin, a company can assess whether or not current practices are working and forecast earnings based on revenue. Because companies express net profit margin as a percentage rather than an amount in euros, it is possible to compare the profitability of two or more businesses regardless of size [27]. Utilisation of assets is important to a company because its success is often linked to its ability to manage and utilise its assets. An optimal asset utilisation ratio means that the company is more efficient with the amount of assets held. Asset usage ratios measure how efficient a business is at using its assets to make money. The turnover of a business, which is defined as its credit sales divided by the value of accounts receivable from customers, indicates whether a business is able to return the goods and services it sells in cash that is 
available for other purposes. Inventory turnover is another ratio of asset utilisation, found by dividing the cost to produce goods sold over a given period of time by the average value of the inventory of the business product over that same period of time.

Capital structure: The term 'structure' means the arrangement of different parts. Capital structure means the regulation of capital from different sources in order to raise the long-term funds needed for the business. Thus, capital structure refers to the proportions or combinations of equity of first stock, equity preference of shares, debts, long-term loans, retained earnings and other long-term sources of funds in the total amount of capital that a firm must raise to run the business. Both debt and equity can be found in the balance sheet. The assets of the company, also listed on the balance sheet, are purchased with this debt and equity. The capital structure can be a mixture of a company's long-term debt, short-term debt, common stock and preferred stock [28]. The percentage of a company's short-term debt versus its long-term debt is considered when analysing its capital structure. When analysts refer to the capital structure, they are likely referring to a firm's debt-to-equity ratio (D / E), which provides insight into the riskiness of a company's borrowing practices. Usually, a debtfinanced company has a more aggressive capital structure and therefore poses a greater risk to investors. However, this risk can be the main source of firm growth [29].

Importance of capital structure:

* Increasing the value of the firm

* Utilising available funds

* Maximising returns

* Minimising the cost of capital

* Liquidity positioning

* Flexibility

* Unperturbed control

Profitability is closely linked to profit - but with one key difference. While profitability is an absolute sum, profit a relative. It is the metric used to determine a company's profit area in relation to the size of the business. Profitability is a measure of efficiency - and ultimately the success or failure of the business. A further definition of profitability is the ability of a business to produce a return on an investment based on its resources compared to an alternative investment. The fact that a company can make a profit does not mean that the company is profitable [30]. Profitability is a business indicator to record the financial success (profit) of a company measured by the capital employed. It distinguishes between total return on equity, return on equity and return on sales. It is the ratio of profit to capital employed by a company. Profitability is the ratio of success (revenue). Profitability is therefore a measure (main figure) of the productivity of capital employed or turnover achieved. The purpose of a profitability calculation is to compare the profitability of different companies and / or different business years of a single company (business comparison). Among other things, it depends on a uniform calculation of profit and uniform completion of profit content and capital sizes.

\section{SMES SECTOR IN KOSOVO: PERFORMANCE, CHARACTERISTICS, ROLE AND SECTORAL STRUCTURE}

'Micro and small' enterprises occupy a large share of a country's economy. The contribution they make to growth, job creation and social development is to be appreciated. In almost all countries in which the capitalist system or even a socialist economy dominates, the definition of SME is not the same in all countries, in which case we can freely conclude that there is no general definition of SME [31]. SMEs make up the bulk of Kosovo's private sector economy and account for approximately $80 \%$ of employment in the market economy. Despite this, however, the importance of the country's SME sector as well as the wider business environment shows some significant weaknesses that prevent this sector from developing its full potential in terms of employment, productivity and value added. Against this background, strengthening and developing the SME sector is a policy priority of the Government of Kosovo, which aims to create a friendly business environment as well as to promote an entrepreneurial culture and increase the competitiveness of SMEs [32].

SME performance: In general, the structure of enterprises in Kosovo in terms of size has remained relatively the same. However, data on SMEs shows progress over the years in terms of realised sales and, consequently, a change in their structure. The number of SMEs generating sales of less than $€$ 10,000 has $67 \%$ to $26 \%$ in 2001 for the total number of SMEs in Kosovo. On the other hand, there has been an increase in the share of those companies that have sales in excess of the annual threshold of $€ 10,000$. It is also worth noting that the share of companies with realised sales of over 1 million euros have increased by $1.2 \%$ in 2011 to a full $4 \%$ of the total number of SMEs in 2016.More than a third of the interviewed enterprises stated that sales in 2016 had a marked increase compared to the previous year. While $32 \%$ stated that this year was characterised by declining sales, the rest stagnated in this regard. Most of the revenues from sales are realised by household Kosovar businesses. On average, $70 \%$ of revenues come from households, while sales between businesses and revenues from various government procurement activities realise on average $26 \%$ and $4 \%$ of total revenues, respectively. It is worth noting that the capacity utilisation rate of Kosovar businesses is relatively satisfactory; in 2016, the average capacity utilisation rate was $70 \%$ compared to the average of $81.6 \%$ for Eurozone countries [33, 34].

Characteristics of SMEs - Before giving a definition of SMEs, their typical characteristics according to some researchers should be identified. In summary, they are as follows:

* They are very flexible. The main competitive advantage of SMEs is their flexibility; often they are able to quickly meet the demands and needs of customers [35].

* They bring innovation. Innovation through a research and development programme is vital to the existence of a typical SME [36].

* They are able to quickly implement decisions. They are characterised by rapid implementation of decisions taken to mitigate external threats and capitalise on opportunities.

* They have vertical integration. SMEs are more vertically integrated than other categories of businesses as there are fewer levels of administration and bureaucracy. This facilitates their management but, on the other hand, has a drawback as SMEs become more focused on operational issues [37].

* Their success depends on the skills of the CEO. The personality of an SME or CEO is a key element in 
managing, growing and succeeding in business. Thus, SMEs are more often people-oriented.

* There is a lack of compliance with labour relations requirements. In SMEs, employment is often free and informal; the standardisation process is missing.

From the statistics obtained from the Statistical Agency of countries, we can conclude that $10 \%$ of the enterprises interviewed during 2016 have been established in the last three years. This shows that the trend in adding new enterprises remains more or less the same. A comparison of the number of SMEs in Kosovo and the region shows that the number of SMEs per 1000 inhabitants in Kosovo is smaller than in other countries in the region where it can be seen in Figure 1 [38].

\section{Number of SMEs per 1000 residents in region}

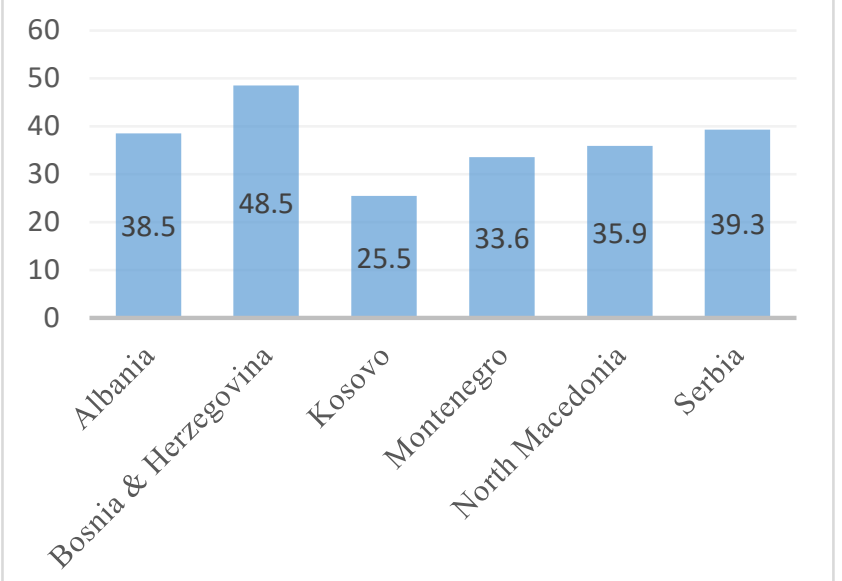

Figure 1. Number of SMEs per 1000 inhabitants in the region

Kosovo and Albania continue to have the lowest average wages among the countries in the region. In Kosovo, the average salary is considered to be higher in the public sector and this has caused Kosavars to view the private sector as a less desirable employer. Moreover, unfavourable working conditions, non-compliance with employment contracts and overtime work often contribute to the private sector being considered an unsafe working environment. The vast majority $(81 \%)$ of enterprises in Kosovo are owned by private owners. In about $8 \%$ of them, directors or managers have the role of enterprise leader, while $11 \%$ of enterprises are jointly led by the owner and the director or manager. Due to their size structure, most businesses in Kosovo do not have a board of directors. According to data, over $90 \%$ of enterprises have stated that they operate without a board, while only $8 \%$ have boards. The latter are mostly medium- and large-sized enterprises which operate as joint stock companies. Most enterprises in Kosovo are locally owned and, according to data, $89 \%$ of businesses are fully local, $6 \%$ foreign owned and the rest with mixed capital. Membership in any business chamber or entrepreneurial association does not play a role for the owners and managers of Kosovar enterprises. Over $80 \%$ of enterprises are not members of any association or organisation. Membership in various organisations or associations has declined systematically in the last 10 years, mainly due to the dominance of micro- and small-sized enterprises that do not see any benefit from membership in these organisations due mainly to the low trust they have in them [39].

Private sector development is closely linked to economic development in a country. A strong private sector is a reflection of a country's development. Kosovo continues to have higher than average economic growth in the Western Balkans region [40]. According to the World Bank, Kosovo has had stable economic growth over three years, with $3.9 \%$ in $2018,4.2 \%$ in 2019 and a forecast of $4.4 \%$ for 2020 . However, this economic growth that was mainly derived from public investment, private consumption and revenue from fat shipments. Despite stable economic growth, the private sector in Kosovo faces many challenges due to a high level of informality and a large number of unaddressed barriers to doing business. The presence of these barriers makes the performance of the private sector in Kosovo unenviable. Over half of SMEs are involved in the trade sector while the manufacturing and information technology sectors are underdeveloped. The vast majority of SMEs are micro and small-sized enterprises. It is assumed that the entry into force of the Stabilization and Association Agreement (SAA) in 2018 will increase the productivity of Kosovo enterprises and have a positive impact on Kosovo's economic growth, but the results remain to be seen. Kosovo at the end of 2017 had an increase in Foreign Direct Investment reaching 287.3 million euros, a large increase compared to the value of 123.8 million euros in the previous year. However, Kosovo's power to attract FDI remains weak compared to countries in the region [41].

\section{COMPARATIVE ANALYSIS OF DUPONT MODEL FINANCIAL INDICATORS}

Table 1 shows the average return on capital and the average profit margin for manufacturing enterprises in Kosovo. In 2016 , the average ROE is $€ 19,588$ while the average PM is $€$ 0.086 ; in 2017 , the average ROE has increased by $€ 4.2564$ and the average PM has increased by $€ 0.0517$. Thus, an increase in the average ROE to 23.8452 will increase the average PM to 0.1382 . In 2018 , there is a decrease in the average ROE by $0.3647 €$ while the average PM is reduced by $0.0011 €$ which will dry with the reduction of the average ROE - at $23.48059 €$ the average PM will reduce to 0.1370 . Figure 2 shows the trend line for the average profit margin for 2016 2018 which indicates that there have not only been increases but also decreases in the last year in terms of $\mathrm{R}$ square. As can be seen in this graph, there is a value of $73 \%$ which means that the profit margin ratio explains the return on equity of $73 \%$, which is a high explanatory nature between the variables [4244].

Table 2 shows the average return on equity and the average assets utilisation for manufacturing enterprises in Kosovo. In 2016 , the average ROE is $€ 19,588$ while the average AU is $€$ 0.9829 ; in 2017 , the average ROE increased by $€ 4.2564$ but the average AU decreased by $€ 0.06647$. So with the increase of the average ROE to 23.8452, the average AU will decrease to 0.9164 .

In 2018 , we have a decrease in the average ROE by $€ 0.3647$ while the average AU will increase by $0.01 €$ which will dry with the reduction of the average ROE - at $€ 23.48059$, the average of AU will also increase to 0.9264 .

Figure 3 shows the trend line for the average assets utilisation for 2016-2018 and indicates that there is an increase and a decrease from year to year in terms of $\mathrm{R}$ square. According to the graph, there is a value of $62 \%$ which means 
that the asset utilisation ratio explains the return on equity of $62 \%$, which is a high explanatory nature between the variables [42-44].

Table 3 shows the average return on equity and the average of the equity multiplier for productive enterprises in Kosovo. In 2016 , the average ROE is $€ 19,588$ while the average EM is $€ 6.2276$; in 2017, the average ROE has increased by $€ 4.2564$ but the average EM has decreased by $€ 1.6217$. So with the increase of the average ROE to 23.8452, the average EM will decrease to 4.6058. In 2018, there is a decrease of the average ROE by $€ 0.3647$, while the average EM decreases by 0.6352 $€$ which will dry with the decrease of the average of the ROE - at $23.48059 €$, the average EM will decrease to 3.9705 . Figure 4 presents the trend line for the average of the equity multiplier for 2016-2018 which shows that there is an increase from year to year. In terms of R square, it has a value of $94 \%$; thus, the of the equity multiplier ratio explains the return on equity of $94 \%$, which is a very high explanatory nature between the variables [42-44].

Table 4 shows the average return on equity and the average profit margin for SMEs in the commercial and service sector in Kosovo. In 2016, the average ROE is $€ 21.00043$ while the average PM is $0.081739 €$; in 2017, the average ROE increased by $4.02566 €$ and the average PM increased by $0.00913 €$. So with the increase of the average ROE to 25.02609, the average PM will increase to 0.106522. In 2018, we have a decrease of the average ROE by $€ 4.02566$ while the average PM increased by $0.00913 €$ which will dry with the reduction of the average of $\mathrm{ROE}$ - that at $24.60957 €$, the average PM will increase to 0.115652 . Figure 5 shows the trend line for the average profit margin for 2016-2018 that indicates an increase from 2016 to 2017 and a decrease in 2018; in terms of R square, it has a value of $93 \%$ which means that the profit margin ratio explains the return on equity for $93 \%$, which is a very high explanatory nature between the variables [42-44].

Table 1. ROE average and profit margin average for manufacturing enterprises in Kosovo (2016-2018)

\begin{tabular}{|c|c|c|}
\hline Years & ROE Average (\%) & Profit Margin Average (\%) \\
\hline $\mathbf{2 0 1 6}$ & 19.58882353 & 0.086471 \\
\hline $\mathbf{2 0 1 7}$ & 23.8452941 & 0.138235 \\
\hline $\mathbf{2 0 1 8}$ & 23.48059 & 0.137059 \\
\hline
\end{tabular}

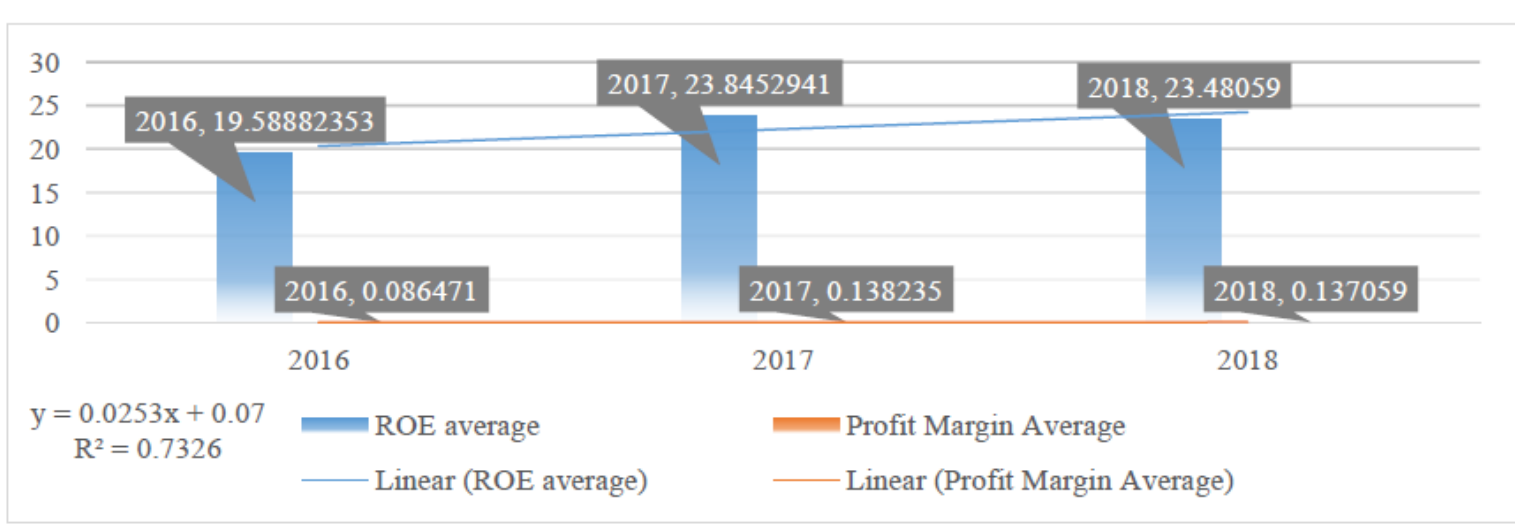

Figure 2. Graphic presentation of the average return on equity (ROE) and profit margin average for the period 2016-2018 by manufacturing companies in Kosovo and the presentation of the linear trends

Table 2. Average ROE and average asset utilisation for manufacturing enterprises in Kosovo (2016-2018)

\begin{tabular}{|c|c|c|}
\hline Years & ROE average (\%) & Average assets utilisation (\%) \\
\hline $\mathbf{2 0 1 6}$ & 19.58882353 & 0.982941 \\
\hline $\mathbf{2 0 1 7}$ & 23.8452941 & 0.916471 \\
\hline $\mathbf{2 0 1 8}$ & 23.48059 & 0.926471 \\
\hline
\end{tabular}

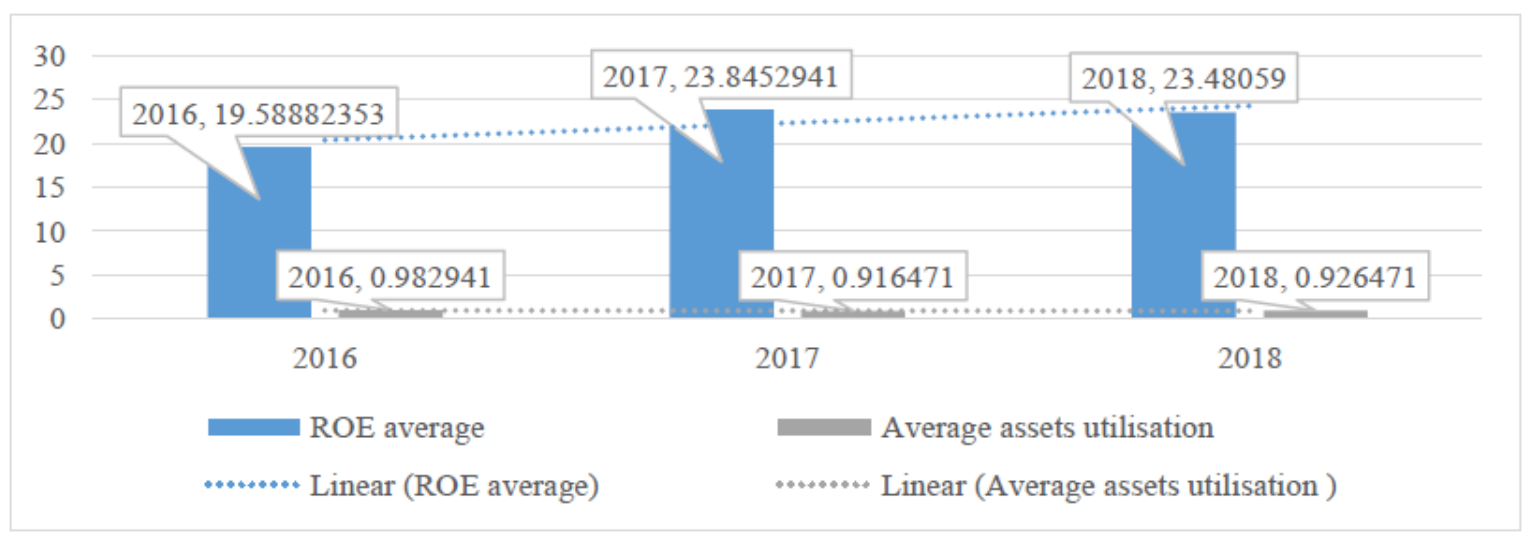

Figure 3. Graphical presentation of the average return on equity (ROE) and average asset utilisation for the period 2016-2018 by manufacturing companies in Kosovo and the presentation of the linear trends 
Table 3. ROE average and average equity multiplier of manufacturing enterprises in Kosovo (2016-2018)

\begin{tabular}{|c|c|c|c|}
\hline Years & ROE average (\%) & & The average of the equity multiplier (\%) \\
\hline $\mathbf{2 0 1 6}$ & 19.58882353 & & 6.227647 \\
\hline $\mathbf{2 0 1 7}$ & 23.8452941 & 4.605882 \\
\hline $\mathbf{2 0 1 8}$ & 23.48059 & 3.970588 \\
\hline
\end{tabular}

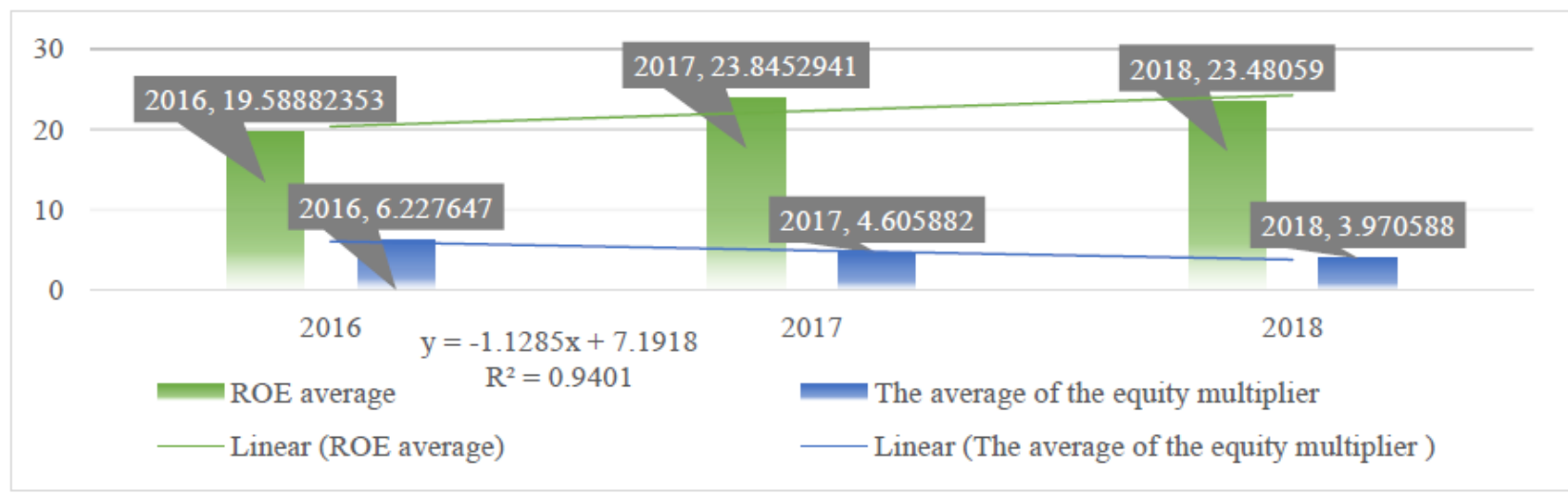

Figure 4. Graphic presentation of the average return on equity (ROE) and the average of the equity multiplier for the period 2016-2018 by manufacturing companies in Kosovo and the presentation of the linear trends

Table 4. Average ROE and profit margin average for SMEs in the commercial and service sector in Kosovo

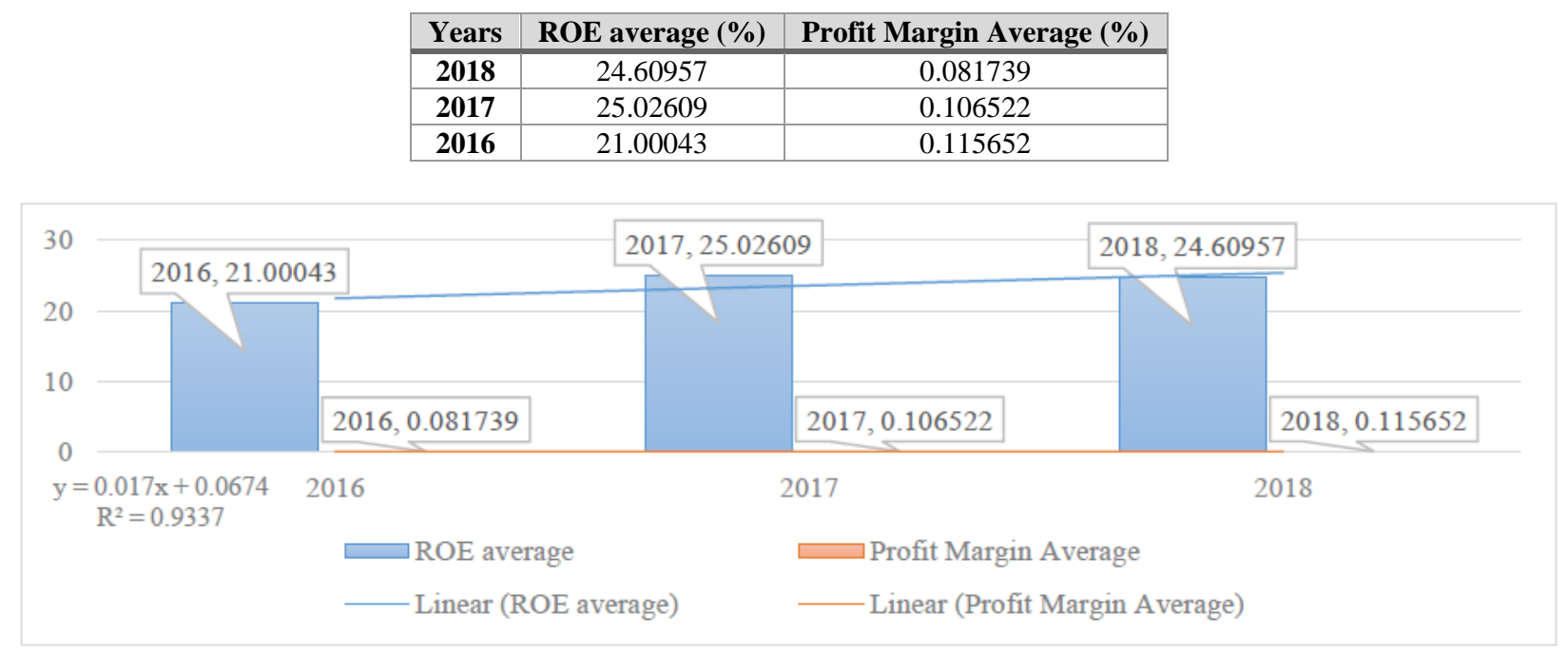

Figure 5. Graphical presentation of the average return on equity (ROE) and profit margin average for the period 2016-2018, by commercial and service enterprises in Kosovo and the presentation of the linear trends

Table 5 presents the average return on equity and the average assets utilisation for SMEs in the commercial and service sector in Kosovo. In 2016, the average ROE is $€$ 21.00043 while the average PM is $€ 1.686364$; in 2017 , the average ROE has increased by $€ 4.02566$ and the average AU has increased by $€ 0.976363$. So the increase of the average ROE to 25.02609 will also increase the average of AU to 2.662727. In 2018, there is a decrease of the average ROE by $0.41652 €$, while the average of AU was reduced by 0.420553 $€$ which will dry with the decrease of the average ROE - that at $24.60957 €$, the average of AU will be reduced to 2.242174 .

Figure 6 shows the trend line for the average asset utilisation for 2016-2018 where it is seen that we have an increase from 2016 to 2017 and a decrease in 2018, in terms of R square that we are seeing in this graph we have a value of $32 \%$ which means that the asset utilisation ratio explains the return on equity for $32 \%$, which is a low explanatory nature between the variables [42-44].
Table 6 shows the average return on equity and the average of the equity multiplier for SMEs in the commercial and service sector in Kosovo. In 2016, the average ROE is $€$ 21.00043, while the average of EM is $3.244783 €$; in 2017, the average of ROE has increased by $4.02566 €$ and the average of EM has increased by $0.205217 €$. So with the increase of the average ROE to 25.02609, the average of EM will increase to 3.45 . In 2018, we have a decrease in the average ROE of $0.41652 €$, and the average of EM will be reduced by $€$ 0.076087 which will dry with the decrease of the average of ROE - that at $€ 24.60957$ the average of EM will be reduced to 3.373913. Figure 7 shows the trend line for the average wealth utilisation for 2016-2018 which indicates that there is an increase from 2016 to 2017 and a decrease in 2018; in terms of R square, the graph shows a value of $38 \%$ which means that the equity multiplier ratio explains the return on equity for $38 \%$, which is a low explanatory nature between the variables [42-44]. 
Table 5. Average ROE and average assets utilisation for SMEs in the commercial and service sector in Kosovo

\begin{tabular}{|c|c|c|}
\hline Years & ROE average (\%) & Average assets utilisation (\%) \\
\hline $\mathbf{2 0 1 6}$ & 21.00043 & 1.686364 \\
\hline $\mathbf{2 0 1 7}$ & 25.02609 & 2.662727 \\
\hline $\mathbf{2 0 1 8}$ & 24.60957 & 2.242174 \\
\hline
\end{tabular}

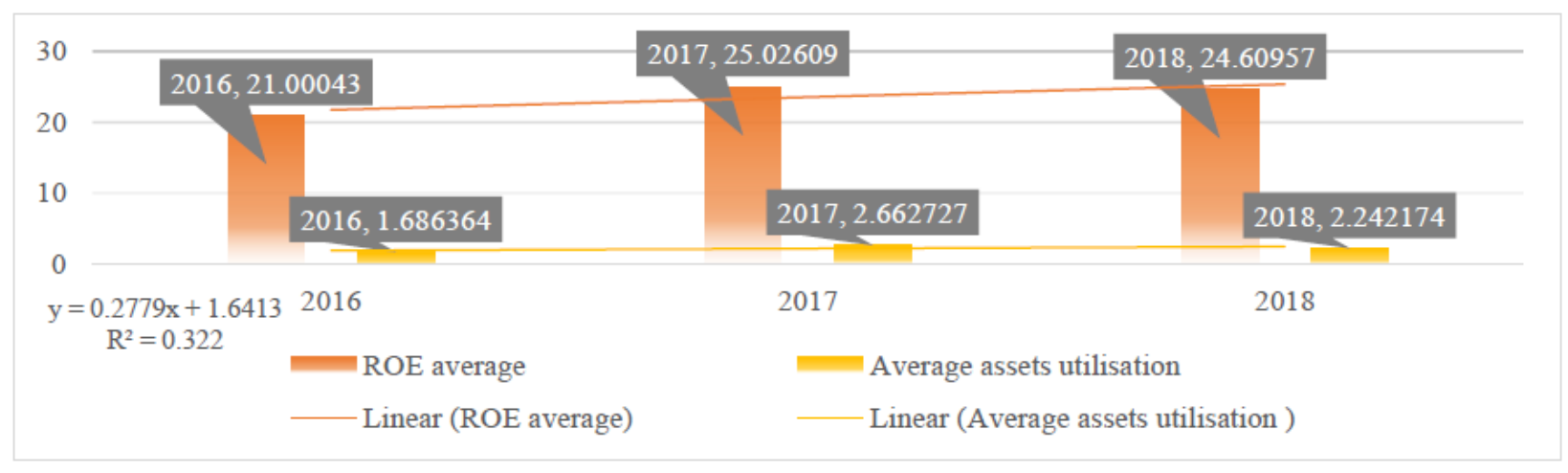

Figure 6. Graphic presentation of the average return on equity (ROE) and the average assets utilisation for the period 2016 2018 by commercial and service enterprises in Kosovo and the presentation the linear trends

Table 6. Average ROE and average of the equity multiplier for SMEs in the business and service sector in Kosovo

\begin{tabular}{|c|c|c|}
\hline Years & ROE average (\%) & The average of the equity multiplier (\%) \\
\hline $\mathbf{2 0 1 6}$ & 21.00043 & 3.244783 \\
\hline $\mathbf{2 0 1 7}$ & 25.02609 & 3.45 \\
\hline $\mathbf{2 0 1 8}$ & 24.60957 & 3.373913 \\
\hline
\end{tabular}

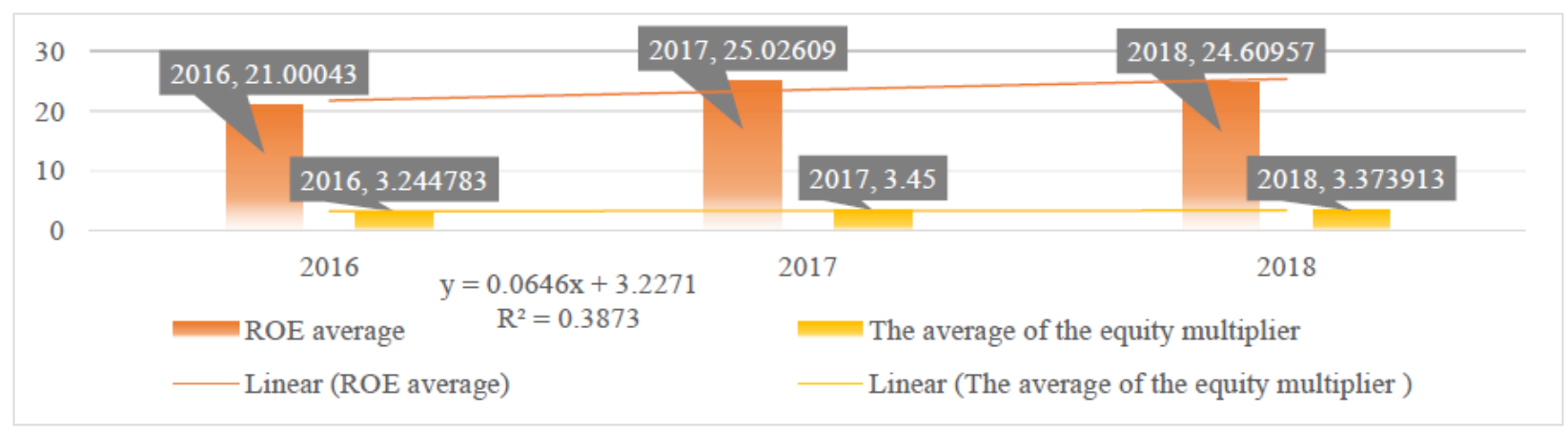

Figure 7. Graphical presentation of the average return on capital (ROE) and the average of the equity multiplier for the period 2016-2018 by commercial and service enterprises in Kosovo and the presentation of the linear trends

\section{SCIENTIFIC RESEARCH METHODOLOGY}

The scientific research methodology which will be applied in this study is based on quantitative methods, applying secondary data. The implementation of the empirical analysis will be based on secondary data from the audited financial statements of small and medium-sized enterprises in Kosovo. The secondary data analyzed in this study are based on financial statements audited by the Office of the Auditor General in Kosovo and published by the Ministry of Finance.

In this context, we plan to include 40 different enterprises covering a period of three years. The enterprises selected in this scientific research are mainly manufacturing, trading and service enterprises. The sample includes different types of enterprises by business activities, as it will be analyzed how different financial factors affect the profitability of different enterprises in Kosovo. First, this data will be analysed, processed and calculated according to the DuPont model. Based on these results, all the necessary interpretations will then be realised to explain which components of profitability have the greatest effect on the activity of these small and medium-sized enterprises. This data will be subjected to comparative analysis by applying the historical trend model, the average trend value and the cumulative average value.

After the data interpretation phase, an econometric analysis will be performed to identify which components of the DuPont model have the greatest influence on the performance of the enterprises selected in this study. Data will be analysed using econometric models through parametric statistical tests, correlation analysis and multifactorial regression analysis. The purpose of this study is to identify the role of SMEs in Kosovo. This study is also intended to carry out a detailed analysis of the DuPoint model using the financial reports of enterprises in Kosovo. Through the use of econometric models, we will test how they affect the asset utilisation ratio, the profit margin ratio and the equity multiplier ratio, as independent variables, with return on equity (ROE) as the dependent variable (ROE). 


\section{Research questions and study hypotheses:}

1. How has the assets utilisation ratio affected the return on equity (ROE)?

H1: The assets utilisation ratio has had a positive impact on the return on equity.

2. How did the profit margin ratio affect the return on equity (ROE)?

H2: Profit margin has had a positive impact on return on equity.

3. How has the equity multiplier affected the return on equity (ROE)?

H3: Equity multiplier has had a positive impact on return on equity.

\section{EMPIRICAL ANALYSIS AND STUDY FINDINGS}

Table 7 presents the description of the variables which are included in this econometric model, the formulas for how these financial reports are calculated and the data sources.

To provide these hypotheses, the equation is modelled:

$Y(R O E)=B o+B_{1} X_{1}(A U)+B_{2} X_{2}(P M)+B_{3} X_{3}(E M)+e_{t}$

$\mathrm{Y}$ - represents the dependent variable (the variable that is explained), which in this research is return on equity.

$\mathrm{X}_{1}, \mathrm{X}_{2}$ and $\mathrm{X}_{3}$ - represents the independent variables, which in this research are asset utilisation ratio, equity multiplier and profit margin ratio.

$\mathrm{B}_{1}, \mathrm{~B}_{2}$ and $\mathrm{B}_{3}$ are defined as evaluation parameters or coefficients; where $\mathrm{B}_{1}$ is the constant parameter while $\mathrm{B}_{2}$ and $\mathrm{B}_{3}$ are the independent variable estimation parameters.

$\mathrm{e}-$ is the term stochastic variable or error, which contains all the factors or variables that are not predicted in the model and is a random and unprotected variable that captures positive and negative values. Statistical error indicates that there are other factors that affect the ROE dependent variable. This indicates that the complete variable is not explained or does not give us information from the independent variables. Otherwise, the statistical component represents the unexplained part of the model.

The descriptive statistics table (Table 8) shows the minimum, maximum, sum, mean and standard deviation of the dependent and independent variables. The minimum dependent variable ROE is negative at -28.11 , the maximum is 98.76 , the average is 22.8854 and the standard deviation is 24.71394. The large negative values of ROE are the result of a bad financial situation in companies that generated losses for several years. The accumulated negative results caused a decline in capital.

The minimum of the independent variable EM is 1.00, the maximum is 74.40 , the average is 4.0160 and the standard deviation is 8.72808. The minimum of the independent variable PM is -0.15 , the maximum is 1.12 , the average is 0.1088 and the standard deviation is 0.16650 . The minimum of the independent variable $\mathrm{AU}$ is 0.18 , the maximum is 29.52 , the average is 1.6862 and the standard deviation is 3.48564 . So all variables have a positive average. The variables ROE and PM have a minimum negative value, while the variables $\mathrm{EM}$ and $\mathrm{AU}$ have a positive value.

The highest minimum value is EM with a value of 1.00. The highest maximum value is the ROE variable with a value of 98.76, while the lowest maximum value is the PM variable with a value of 1.12. ROE has the highest standard deviation at 24.71394, while the standard deviation with the lowest value is PM.

The hypothesis put forward for testing is:

$\boldsymbol{H}_{0}$ - Assets utilisation ratio does not affect the return on equity.

$\boldsymbol{H}_{1}-$ Assets utilisation ratio affects return on equity.

$\boldsymbol{H}_{\boldsymbol{0}}$ - Profit margin ratio does not affect the return on equity.

$\boldsymbol{H}_{2}-$ Profit margin ratio affects return on equity.

$\boldsymbol{H}_{\boldsymbol{0}}-$ Equity multiplier does not affect the return on equity.

$\boldsymbol{H}_{3}-$ Equity multiplier affects the return on equity.

Table 7. Description and formulation of model and data source variables

\begin{tabular}{lccc}
\hline Variables & Description & Formulas & Data source \\
\hline Y (ROE) & Return on Equity (\%) & ROE $=\frac{\text { Net profit }}{\text { equity }}$ & Annual Enterprise Reports \\
$\mathrm{X}_{1}(\mathrm{AU})$ & Assets Utilisation Ratio (\%) & $\mathbf{A U}=\frac{\text { selling }}{\text { Total assets }}$ & Annual Enterprise Reports \\
$\mathrm{X}_{2}(\mathrm{EM})$ & Equity Multiplier (\%) & $\mathbf{E M ~}=\frac{\text { Total assets }}{\text { Equity }}$ & Annual Enterprise Reports \\
$\mathrm{X}_{3}(\mathrm{PM})$ & Profit Margin $(\%)$ & $\mathbf{P M ~}=\frac{\text { Net profit }}{\text { Sales }}$ & Annual Enterprise Reports \\
\hline
\end{tabular}

Table 8. Descriptive statistics for the variables included in the econometric model

\begin{tabular}{ccccccc}
\hline Variables & N & Minimum & Maximum & Sum & Mean & Std. Deviation \\
\hline ROE & 120 & -28.11 & 98.76 & 2746.25 & 22.8854 & 24.71394 \\
AU & 120 & .18 & 29.52 & 202.34 & 1.6862 & 3.48564 \\
EM & 120 & 1.00 & 74.40 & 481.92 & 4.0160 & 8.72808 \\
PM & 120 & -.15 & 1.12 & 13.05 & .1088 & .16650 \\
\hline
\end{tabular}

Table 9. Model summary

\begin{tabular}{|c|c|c|c|c|c|c|c|c|c|c|}
\hline \multirow[t]{2}{*}{ Model } & \multirow[t]{2}{*}{$\mathbf{R}$} & \multirow{2}{*}{$\begin{array}{c}\text { R } \\
\text { Square }\end{array}$} & \multirow{2}{*}{$\begin{array}{l}\text { Adjusted R } \\
\text { Square }\end{array}$} & \multirow{2}{*}{$\begin{array}{l}\text { Std. Error of the } \\
\text { Estimate }\end{array}$} & \multicolumn{5}{|c|}{ Change Statistics } & \multirow{2}{*}{$\begin{array}{l}\text { Durbin- } \\
\text { Watson }\end{array}$} \\
\hline & & & & & $\begin{array}{l}\text { R Square } \\
\text { Change }\end{array}$ & $\begin{array}{c}\mathrm{F} \\
\text { Change }\end{array}$ & df1 & df 2 & $\begin{array}{c}\text { Sig. F } \\
\text { Change }\end{array}$ & \\
\hline 1 & $.625^{\mathrm{a}}$ & .391 & .375 & 19.53117 & .391 & 24.845 & 3 & 116 & .000 & 1.135 \\
\hline
\end{tabular}


Table 9 presents in summary form the coefficients of correlation, determination, autocorrelation and some other important data for the stability of the econometric model.

Correlation and determination coefficient - from the results of the regression analysis, the model has a correlation coefficient of $62.5 \%$ which shows an average correlation between the dependent variable and other independent variables.

The coefficient of determination - the value of the coefficient of determination is $39.1 \%$ which indicates an average explanatory value between the values of $\mathrm{X}$ and $\mathrm{Y}$. But it does not mean that this model is incorrect. Error term - The value of the error term is $60.9 \%$ which means that this econometric model has an average degree of expediency $(39.1 \%)$ and the value of the error term is high. This value indicates that in the econometric model, a large number of factors which affect Return on Equity are not taken into account.

The value of the autocorrelation through the Durbin Watson coefficient is 1.135 which indicates that this econometric model has an average negative autocorrelation. But since the value of this coefficient is below its preferred values, we can say that this econometric model is correct. This means that we have no interdependence between independent variables.

Table 10 presents the results of the analysis of variance for the variables which are included in this econometric analysis.

F-Test $24.845>3.10$ - Based on the results of the F-test, if the actual value is greater than the critical value, then the basic hypothesis is rejected and the alternative hypothesis is accepted.

Based on the results of the analysis of variation we can conclude that the model as a whole is correct since the value of the significance is $0.00<0.05$. Is there multicollinearity in the model - This econometric model as a whole does not have inaccurate multicollinearity (correlation) between independent variables. This correlation is observed in all independent variables because these variables are below the significance level.

Table 11 presents the results of the regression analysis which show the validity of the hypotheses presented in this study. This table shows the regression coefficients, standard error values, T-test results, significance level and confidence interval.

Ratios - valuers for $b_{0}, b_{1}$, and $b_{2}-B_{0}$ - If asset utilisation $\left(\mathrm{X}_{1}\right)$, profit margin ratio $\left(\mathrm{X}_{2}\right)$ and equity multiplier $\left(\mathrm{X}_{3}\right)$ are constant or 0 then the return on equity will be 7.753 units. This statement is correct because the significance value is within the confidence interval $(0.003<0.05)$.

$\mathrm{B}_{1}$ - If asset utilisation increases by one unit then return on equity will increase by $2.958 \%$ (units), keeping constant the profit margin ratio and equity multiplier. This statement is correct because the significance level is below its standard level $(0.000<0.05)$.

$\mathrm{B}_{2}$ - If the profit margin ratio increases by one percent or one unit then the return on equity will increase by $74.853 \%$ (units) keeping the asset utilisation and capital multiplier constant. This statement is correct because the significance level is below its standard level $(0.000<0.05)$.

$\mathrm{B}_{3}$ - If the equity multiplier increases by one unit (or \%), then the return on equity will increase by $0.209 \%$ (units) keeping the asset utilisation and profit margin ratio constant. This statement is correct because the significance level is below its standard level $(0.018<0.05)$.

Standard errors of parameters $b_{0}, b_{1}, b_{2}$, standard model error - Standard error for parameter $b_{0}=2.542, b_{1}=0.521, b_{2}$ $=10.962, b_{3}=0.209$. The standard error of the model as a whole is 19.53117 , and if we rely on the graph of the linear correlation between $\mathrm{X}$ and $\mathrm{Y}$, then we notice that the points of the regression line are far straight; based on this, it is observed that the value of the standard error of the model parameters are lower values that do not indicate accuracy between the $\mathrm{X}$ and Y variables.

Table 10. Results of analysis of variance (ANOVA)

\begin{tabular}{ccccccc}
\hline & Model & Sum of Squares & Df & Mean Square & F & Sig. \\
\hline \multirow{4}{*}{1} & Regression & 28432.528 & 3 & 9477.509 & 24.845 & $.000^{\mathrm{b}}$ \\
& Residual & 44250.139 & 116 & 381.467 & & \\
\hline & Total & 72682.667 & 119 & & & \\
\hline
\end{tabular}

Table 11. Coefficient

\begin{tabular}{|c|c|c|c|c|c|c|c|c|c|c|c|}
\hline & \multirow{2}{*}{ Model } & \multicolumn{2}{|c|}{$\begin{array}{l}\text { Unstandardized } \\
\text { Coefficients }\end{array}$} & \multirow{2}{*}{$\begin{array}{c}\text { Standardised } \\
\text { Coefficients } \\
\text { Beta }\end{array}$} & \multirow{2}{*}{ t } & \multirow{2}{*}{ Sig. } & \multicolumn{2}{|c|}{$\begin{array}{l}\text { 95.0\% Confidence } \\
\text { Interval for B }\end{array}$} & \multicolumn{3}{|c|}{ Correlations } \\
\hline & & B & Std. Error & & & & $\begin{array}{l}\text { Lower } \\
\text { Bound }\end{array}$ & $\begin{array}{l}\text { Upper } \\
\text { Bound }\end{array}$ & $\begin{array}{l}\text { Zero- } \\
\text { order }\end{array}$ & Partial & Part \\
\hline \multirow{4}{*}{1} & (Constant) & 7.753 & 2.542 & & 3.049 & .003 & 2.717 & 12.788 & & & \\
\hline & $\mathrm{AU}$ & 2.958 & .521 & .417 & 5.675 & .000 & 1.925 & 3.990 & .368 & .466 & .411 \\
\hline & PM & 74.853 & 10.962 & .504 & 6.828 & .000 & 53.141 & 96.566 & .420 & .535 & .495 \\
\hline & EM & .499 & .209 & .176 & 2.394 & .018 & .086 & .912 & .148 & .217 & .173 \\
\hline
\end{tabular}

Table 12. Variables of parameter estimators $b_{0}, b_{1}, b_{2}$, and error term variation

\begin{tabular}{ccc}
\hline Coefficients & Calculation & $\begin{array}{c}\text { Value of } \\
\text { parameters }\end{array}$ \\
\hline $\mathbf{B}_{\mathbf{0}}$ & $2.542^{2}$ & 6.461764 \\
$\mathbf{B}_{\mathbf{1}}$ & $0.521^{2}$ & 0.271441 \\
$\mathbf{B}_{\mathbf{2}}$ & $10.962^{2}$ & 120.165444 \\
$\mathbf{B}_{\mathbf{3}}$ & $0.209^{2}$ & 0.043681 \\
$\mathbf{e}$ & $0.566^{2}$ & 0.320356 \\
\hline
\end{tabular}

Table 12 shows the results of the variations of the econometric model parameters and the variation of the error term. Test - confirm the hypotheses on the importance of the model parameters as well as on the general importance of the model with significance level $\mathrm{a}=0.05$.

$\mathbf{X}_{1}$ : Assets Utilisation affects of a Return on Equity (5.675 > $2.086)$ - Since the actual value is higher than the critical value, then the basic hypothesis $\left(\mathrm{H}_{0}\right)$ falls and the alternative hypothesis $\left(\mathrm{H}_{1}\right)$ is accepted; then the value of the significance is within its standard level and is less than 0.05 . 
$\mathbf{X}_{2}$ : Profit Margin Ratio affects Return on Equity (6.828 > 2.086) - Based on this result the basic hypothesis $\left(\mathrm{H}_{0}\right)$ is made and the alternative hypothesis $\left(\mathrm{H}_{2}\right)$ is accepted. Then the value of the significance is within its standard level and is less than 0.05 .

X3: Capital Multiplier affects Return on Equity (2.394 > 2.086) - Since the actual value of parameter B3 is higher than the critical value, then the alternative hypothesis $\left(\mathrm{H}_{3}\right)$ is accepted and the basic hypothesis $\left(\mathrm{H}_{0}\right)$ falls. Then the value of the significance is within its standard level and is less than 0.05 .

\section{CONCLUSIONS AND RECOMMENDATIONS}

Success in the general sphere and especially in the financial sphere depends on making the right decisions regarding the destination of cash, both through the prism of personal family finance and through the prism of investments in financial markets. In order to realise a proper investment, financial analysis is needed, while in order to realise a proper financial analysis, there must be a lot of data that must be systematised and analysed.

In the theoretical part of this research, the most important issues in the process of evaluating the success of small- and medium-sized enterprises were addressed, starting from their importance to the evaluation of financial reports through analysis and financial indicators of various types. We can conclude that small- and medium-sized enterprises are of very great importance in the economy of a country.

In the research part, 40 small- and medium-sized enterprises were analysed based on financial reports for the last three years, calculating them with the DuPont model. For the analysis of this data, the econometric model was used to estimate the relationship between the dependent variable of return on capital (ROE) and the independent variables of asset utilisation (AU), capital multiplier (EM) and profit margin (PM).

The above findings clearly show that the first research hypothesis can be considered and confirmed. The use of assets affects the return on capital, and this hypothesis is confirmed based on the results. The second research hypothesis is confirmed, as the profit margin ratio affects the return on equity and this means that the baseline hypothesis is accepted on the basis of results.

The third hypothesis of this research is accepted since the capital multiplier affects the return on capital, and this is confirmed based on the results above.

What should not be forgotten is that additional information should always be sought during the analysis process because a proper analysis should be done by comparing data from as many information sources as possible. The more information we have, the closer we are to the truth and the prediction of the future.

These companies based on an analysis of their statements are seen to be extremely liquid and have no problem with writing off their short-term liabilities at any time. Another recommendation is due to the extremely low rate of long-term liabilities, which means that companies do not like long-term debt, but it also highlights the fact that in Kosovo, sources of financing from abroad are irrational. In addition, this company has a net profit which has a trend of continuous reduction as well as operating expenses that remain almost constant over several years. It is worth noting that SMEs in 2018 had negative values for net profit and had a higher value of operating expenses and depreciation expenses compared to the previous two years.

Based on the empirical results of this study, we conclude that the enterprises included in this research are very liquid, as these companies carefully manage their liquidity needs by carefully monitoring debt payments for long-term financial liabilities as well as projected cash inflows and outflows of money from daily business activities. Given the fact that the objectives of capital management companies are to maintain their solvency, we recommend that these companies continue their activity on the principle of continuity in order to provide returns to shareholders and benefits to other parties and maintain an optimal capital structure to reduce the cost of capital. In order to maintain and adjust the capital structure, we recommend that companies can adjust the amount of dividends paid to shareholders, return capital to shareholders, issue new shares, or sell assets to reduce debt.

\section{REFERENCES}

[1] Asllanaj, Rr. (2010). Kontabiliteti Financiar (Financial Accounting). University of Prishtina, pp. 1-597.

[2] Ahmeti, S. (2012). Kontabiliteti Financiar (Financial Accounting). University of Prishtina, pp. 1-285.

[3] Xhafa, H. (2014). Analiza e Pasqyrave Financiare (Financial Analysis Statement). University of Tirana, pp. $1-445$.

[4] Liberto, D. (2019). Small and Mid-size Enterprise (SME). https://www.investopedia.com/terms/s/smallandmidsize enterprises.asp accessed on Oct. 102020.

[5] Aliriani, K. (2012). Role of small and medium enterprises in the economy: The case of Yemen. Challenges for the Future, International Conference, London, pp. 1-28. https://www.researchgate.net/publication/323116205_R ole_of_Small_and_Medium_Enterprises_in_the_Econo my_The_Case_of_Yemen.

[6] Carlson, R. (2019). Using the dupont model for ROI analysis. The Balance Small Business. https://www.thebalancesmb.com/how-to-calculate-thedupont-model-for-roi-analysis-393229, accessed on Oct. 102020.

[7] Demmer, M. (2015). Improving profitability forecasts with information on earnings quality. Free University Berlin, School of Business \& Economics. https://ideas.repec.org/p/zbw/fubsbe/201516.html

[8] Collier, H.M. (2006). Financial analysis of financial institutions in an. University of Wollongong. Faculty of Business Research. https://www.uow.edu.au/study/accounting-financeeconomics/?utm_source=google\&utm_medium $=$ ppc\&ut $\mathrm{m} \_$campaign $=$centralBAL\&gclid $=$EAIaIQobChMI4Zvf yY̌Kw7gIVvBAGAB0vRAYQEAAYAiAAEgI2yPD_ BwE\&gclsrc $=$ aw.ds, accessed on Oct. 10, 2020.

[9] Almazari, A. (2012). Financial Performance Analysis of the Jordanian Arab by Using the DuPont System of Financial Analysis: International Journal of Economics and Finance, $\quad$ p. 1-94. http://www.ccsenet.org/journal/index.php/ijef/article/vie w/15913

[10] Rogova, E. (2014). DuPont analysis of the efficiency and investment appeal of Russian oil-extracting companies: The 8th International Scientific Conference Business and 
Management.

https://www.researchgate.net/publication/269057100_D upont_Analysis_Of_The_Efficiency_And_Investment_ Appeal_Of_Russian_Oil Extracting_Companies.

[11] Brigham, E.F., Houston, J.F. (2020). Fundamentals of financial management. Cengage Products are Represented in Canada by Nelson Education, 1-705.

[12] Shubita, M. (2019). The DuPont model effect on corporation value. Amman Arab University / Jordan, pp. 1-11. https://www.researchgate.net/publication/337316444_T he DuPont Model Effect on Corporation Value.

[13] Misiri, V., Mazreku, S. (2021). Financial analysis of commercial banks in Kosovo. Academy of Accounting and Financial Studies Journal, 25(1).

[14] Harman. (1976). DuPont Enterprise Financial Analysis. https://www.ukessays.com/essays/statistics/dupontenterprise-financial-analysis.php, accessed on Oct. 18, 2020.

[15] Fuad, M., Mastuti, R., Syaila, C (2019). Financial performance assessment of LQ45 companies using DuPont analysis during the period of 2013-2017. Department of Management, Faculty of Economics, Universitas Samudra Kampus Meurandeh, Kota Langsa, Indonesia,

$1-17$. https://www.researchgate.net/publication/336821623_Fi nancial_Performance_Assessment_of_LQ45_Companie s_using_DuPont_Analysis_during_the_Period_of_2013 -2017 .

[16] Buyukarikan, U., Eryılmaz, C. (2020). Analysis of Financial performance of businesses in the agriculture sector with DuPont model. Erzincan University Journal of Social Sciences Institute, 129-141. https://www.researchgate.net/publication/348009022_T arim_Sektorundeki_Isletmelerin_Finansal_Performansi nin_DuPont_Modeliyle_Analizi_Analysis_of_Financial _Performance_of_Businesses_in_the_Agriculture_Sect or_with_DuPont_Model.

[17] Koşan, L., Karadeniz, E. (2014). Investigation of the accommodation and food service activities subsector financial performance by using the Dupont system of financial analysis (Konaklama ve Yiyecek Hizmetleri Alt Sektörünün Finansal Performansının Dupont Finansal Analiz Sistemi Kullanılarak İncelenmesi). Mersin Üniversitesi,

75-89.

https://www.researchgate.net/publication/278032426_In vestigation_of_The_Accommodation_and_Food_Servic e_Activities_Subsector_Financial_Performance_By_Us ing_The_Dupont_System_of_Financial_Analysis_Kona klama_ve_Yiyecek_Hizmetleri_Alt_Sektorunun_Finans al_.

[18] Turner, J., Broom, K., Elliott, M (2015). A Decomposition of hospital profitability: An application of DuPont analysis to the US market. Health Services Research and Managerial Epidemiology, 1-10. https://www.researchgate.net/publication/276144803_A _Decomposition_of_Hospital_Profitability_An_Applica tion_of_DuPont_Analysis_to_the_US_Market.

[19] Karadeniz, E., Koşan, L., Günay, F., Kahiloğulları, S (2019). Measuring variables affecting profitability by using DuPont analysis technique in hotel companies: An econometric analysis in European stock exchanges. The Journal of Accounting and Finance, 21-36.
[20] Botika, M. (2012). The use of DuPont analysis in abnormal returns evaluation: empirical study of Romanian market: Procedia - Social and Behavioral Sciences, 62: 1179-1183. https://www.researchgate.net/publication/271881003_T he_use_of_DuPont_Analysis_in_Abnormal_Returns_E valuation_Empirical_Study_of_Romanian_Market.

[21] Risal, N. (2019). Performance scrutiny of Nepal electricity authority using DuPont analysis. PYC Nepal Journal of Management, XII(1): 79-85. https:/www.researchgate.net/publication/343603980_P erformance_Scrutiny_of_Nepal_Electricity_Authority_ using_DuPont_Analysis.

[22] Kim, H. (2016). A study of financial performance using DuPont analysis in food distribution market. School of Hospitality \& Tourism Management, Kyungsung University, Korea, 52-60.

[23] Oriskóová, D., Pakšiová, R. (2018). Dupont analysis of companies in the Slovak republic engineering industry. Faculty of Economic Informatics University of Economics in Bratislava, 383-390.

[24] Kennon, J. (2019). The DuPont model return on equity formula for beginners. https://www.thebalance.com/thedupont-model-return-on-equity-formula-for-beginners357494, accessed on Oct. 10, 2020.

[25] Mohammed, N. (2013). Is return on equity (ROE) a good proxy for firm performance to understand CEO compensation system. International Journal of Scientific \& Engineering Research, 4(2): 1-5.

[26] Bryan, R. (2020). How to calculate that obligation with an equity multiplier. https://de.spazziodecor.com/howto-calculate-debt-ratio-using-an-equity-multiplier-10648, accessed on Oct. 18, 2020.

[27] Murphy, C.H. (2020). Net Profit Margin. https://www.investopedia.com/terms/n/net_margin.asp\# : : :text $=$ The $\% 20$ net $\% 20$ profit $\% 20$ margin $\% 20$ is, $\mathrm{a} \% 20$ co mpany\%20or\%20business\%20segment.\&text $=$ The $\% 20$ net $\% 20$ profit $\% 20$ margin $\% 20$ illustrates, $\mathrm{a} \% 20$ company $\% 20$ translates $\% 20$ into $\% 20$ profit.

[28] Goyal, A. (2013). The impact of capital structure on performance of listed public sector banks in India. International Journal of Business and Management Invention, $35-43$. https://issuu.com/invention.journals/docs/e0210103504 3

[29] Abor, J. (2008). The effect of capital structure on profitability: An empirical analysis of listed firms in Ghana. The Journal of Risk Finance, 1-14. https://www.researchgate.net/publication/46546619_Th e_effect_of_capital_structure_on_profitability_An_emp irical_analysis_of_listed_firms_in_Ghana.

[30] Melissa, H. (2019). The $\overline{\text { difference }}$ between profitability and profit. https://www.investopedia.com/ask/answers/012715/wha t-difference-between-profitability-and-profit.asp, accessed on Oct. 10, 2020.

[31] Mustafa, M., Kutllovci, E., Gashi, P., Krasniqi, B. (2006). Biznesi i Vogel dhe i Mesem: Krijimi, Menaxhimi dhe Rritja e Bizneseve: Riinvest Institute for Development Research, Prishtine, Kosovo, pp. 1-477. https://www.researchgate.net/publication/280571123_B iznesi_i_Vogel_dhe_i_Mesem_Krijimi_Menaxhimi_dh e_Rritja_e_Bizneseve. 
[32] Strategjia për Zhvillimin e Sektorit Privat 2018-2022: Ministria e Tregtisë dhe Industrisë - Ministarstvo Trgovine i Industrije - Ministry of Trade and Industry, pp. $1-58$.

https://konsultimet.rksgov.net/viewConsult.php?Consult ationID $=40382$.

[33] Vokrri, V., Gashi, D., Hoxha, F., Beqiri, G., Abdixhiku, L., Hashani. (2017). Klima e biznesit në Kosovë nga perspektiva e NVM-ve: INSTITUTI RIINVEST Lidhja e Prizrenit nr. 42 Prishtinë 10000, Republika e Kosovës, pp. $1-45$ https://www.riinvestinstitute.org/uploads/files/2017/Ma y/19/Klima e Biznesit1495199235.pdf.

[34] Trading Economics Euro Area Capacity Utilization 1985-2020. https://tradingeconomics.com/euroarea/capacity-utilization, accessed on Oct. 10, 2020.

[35] Mansour, T., Abdelazez, M., Eleshmawiy, K., Abd ElGhani, S. (2018). The role of small and medium enterprises in economic development. The International Journal of Business Management and Technology, 2(5): 165-173.

[36] McAdam, R., Antony, J., Kumar, M., Hazlett, S.H. (2011). Absorbing new knowledge in small and mediumsized enterprises: A multiple case analysis of Six Sigma: International Small Business Journal, 81-109.

[37] Jaensson, J. (2017). Innovation for growth of SME's in Tanzania. Open University of Tanzania, 1-13.
[38] Mcadam, R., Keogh, W. (2004). Transitioning towards creativity and innovation measurement in SMEs. Creativity and Innovation Management, 30(3).

[39] INSTAT. (2020). Statistical data for SMEs in Albania. http://www.instat.gov.al/al/statistika/, accessed on Nov. $25,2020$.

[40] Annual Report of the Central Bank of Kosovo. (2019). https://bqk-kos.org/wpcontent/uploads/2020/10/BQK RV 2019.pdf, Nov. 25, 2020.

[41] Strategjia kombëtare për inovacion dhe ndërmarrësi: Ministria e Inovacionit dhe Ndërmarrësisë, pp. 1-56. https://konsultimet.rksgov.net/Storage/Consultations/15-02-2924122018/1.\%20Strategjia\%20Kombetare\%20per\%20I novacion $\% 20 \mathrm{dhe} \% 20 \mathrm{Ndermarresi}$ Shqip.pdf.

[42] Ministry of Finance. (2016). Independent auditor's reports and financial statements. https://mf.rksgov.net/page.aspx?id=1,103, accessed on June 10, 2020.

[43] Ministry of Finance. (2017). Independent auditor's reports and financial statements. https://mf.rksgov.net/page.aspx?id=1,103, accessed on June 10, 2020.

[44] Ministry of Finance. (2018). Independent auditor's reports and financial statements. https://mf.rksgov.net/page.aspx?id=1,103, accessed on June 10, 2020. 